\title{
VIOLÊNCIA E ÉTICA NAS IMAGENS DO JORNAL TRIBUNA DO PARANÁ
}

\section{VIOLENCE AND ETHICS ON TRIBUNA DO PARANÁ IMAGES}

\author{
Andressa Kaliberda* \\ Carlos Alberto de Souza**
}

\begin{abstract}
RESUMO
O jornal Tribuna do Paraná é o segundo periódico mais vendido do estado, com uma tiragem média de 30 mil exemplares diários, contra 40 mil da Gazeta do Povo. Por meio de análise quantitativa e qualitativa, foi identificado e analisado o tratamento dado às imagens de violência na capa e páginas policiais do diário, entre 01 de dezembro de 2010 e 23 de fevereiro de 2011. A análise foi feita através da construção de uma tabela que classifica as imagens entre o grau zero, no qual não há imagens de cunho violento, e o grau 5, em que a morte aparece como tema central. 68\% das imagens coletadas apresentam algum grau de violência; destas, $15 \%$ estão inseridas na capa do jornal e $85 \%$, nas páginas policiais. Através dessa análise pode-se observar o caráter sensacionalista e pouco preocupado com os ditames éticos que permeiam a profissão do jornalismo no periódico.
\end{abstract}

Palavras-chave: Fotojornalismo. Violência. Ética. Sensacionalismo.

\begin{abstract}
Tribuna do Paraná is the second top-selling newspaper in the state of Paraná, with an average circulation of 30 thousand copies daily, competing with the 40 thousand copies sold by the Gazeta do Povo. Through a quantitative and qualitative analysis, the treatment given to violent images was identified and analyzed on covers and police pages, from December, 1st 2010 to February, 23rd 2011. The analysis was done by the construction of a chart that classifies images according to degrees from zero, when there is no violence to five, when death appears as the central theme. $68 \%$ of the collected images show some degree of violence, from which $15 \%$ are on the cover and $85 \%$ on police pages. Through this analysis, the sensationalist character and the lack of worry with ethical dictates of the journalism can be observed in this publication.
\end{abstract}

Keywords: Photojournalism. Violence. Ethics. Sensationalism.

\footnotetext{
* Graduanda do Curso de Jornalismo da Universidade Estadual de Ponta Grossa. Email: andressakaliberda@yahoo.com.br

** Doutor em Ciência Humanas pela Universidade Federal de Santa Catarina. Professor do Curso de Jornalismo da Universidade Estadual de Ponta Grossa. Email: <carlossouza2013@hotmail.com>
} 


\section{Introdução}

A imagem ocupa cada vez mais espaço no jornalismo nacional. O significado da imagem depende dos âmbitos percorridos durante o processo comunicativo, conforme cita JOLY (1996, p.13):

Compreendemos que indica algo que, embora nem sempre remeta ao visível, toma alguns traços emprestados do visual e, de qualquer modo, depende da produção de um sujeito: imaginária ou concretamente, a imagem passa por alguém que a produz ou reconhece.

Assim, a produção imagética deve ser compreendida em seus diversos aspectos, já que a produção de sentido pode ser dada pelo produtor da imagem, mas também depende da interpretação do leitor, que dará significação final à mensagem.

A fotografia tem papel fundamental no jornalismo, uma vez que, já tendo sido percebida como registro verossímil do fato noticiado, hoje tem poder ilustrativo sobre a matéria, além de contribuir para a transmissão da informação dentro do contexto jornalístico. “A foto é percebida como uma espécie de prova, ao mesmo tempo necessária e suficiente, que atesta indubitavelmente a existência daquilo que mostra.” (DUBOIS, 1994, p.25). Segundo Dubois, a fotografia é considerada prova irrefutável da realidade, já que é produzida através do congelamento de uma parte daquilo que é real. Entretanto, quando se trata da fotografia utilizada como fonte jornalística, a mesma trata apenas de um recorte da realidade, não podendo ser usada como único registro dela.

Além disso, a fotografia tem papel fundamental de atrair a atenção do leitor para o texto a que se refere, conforme afirma Lima (1989, p.19): “A função da fotografia no jornal é chamar a atenção para a notícia antes de ela ser lida”. Desse modo, a fotografia age como chamariz para o público, que visualiza a notícia primeiramente na imagem e depois disso migra para o texto, a fim de descobrir maiores informações, que lhe possibilitem compreender o contexto dos fatos noticiados.

Dessa forma, é necessária a análise do conteúdo e da forma de tratamento das imagens por parte dos periódicos, principalmente no que se refere às imagens de violência, uma vez que estas são facilmente alvo das principais falhas éticas cometidas pelos periódicos, como é o caso da análise desenvolvida no diário paranaense Tribuna do Paraná.
O jornal Tribuna do Paraná é editado em Curitiba, desde 1956. Criado no dia 17 de outubro daquele ano pelo repórter Luiz Carlos Alborghetti, nos fundos do jornal Estado do Paraná, possui uma tiragem de cerca de 30 mil exemplares diários, contra 40 mil da Gazeta do Povo.

Firmado no tripé violência, sexo e futebol, o jornal tem como principais editorias as chamadas "De Letra”, voltada ao esporte, e "Segurança Pública”, na qual são pautados diariamente assuntos relacionados a acidentes, morte e violência. O tratamento enfático dado a essas imagens está entre as principais características do periódico. Além da exploração das cores fortes, como o vermelho e preto, fotos de morte, acidentes e cenas chocantes, existem as legendas e títulos compostos de expressões chocantes que impressionam e chamam o leitor para o texto. Essa forma de fazer jornalístico vai de encontro com aquilo que é aceito pelo Código de Ética do jornalismo brasileiro, já que fere seus preceitos fundamentais.

Barthes (1984, p.2) afirma que “a estrutura da fotografia não é uma estrutura isolada; ela comunica pelo menos com uma outra, que é o texto (título, legenda ou artigo) de que qualquer fotografia de imprensa vem acompanhada.” Essas estruturas interagem no processo comunicacional mesmo podendo ter significação independentemente de estarem acompanhadas umas das outras. Elas são, portanto, estruturas independentes. Desse modo, é necessário que cada uma dessas partes componentes da notícia seja estudada individualmente, para que se possa ter pleno conhecimento do conteúdo da mensagem transmitida por meio delas. Dessa forma, o presente trabalho visa compreender quantitativa e qualitativamente o tratamento dado às imagens de violência no jornal Tribuna do Paraná. Pretende-se verificar se esse diário apela para o sensacionalismo e morte a fim de atrair leitores, e confrontar as atitudes do periódico com o Código de Ética dos Jornalistas. Isso para que se possa ter clareza quanto às preocupações nesse âmbito quando se trata de publicar fotografias com temáticas voltadas a assassinatos, estupros ou acidentes, na primeira página e na editoria de polícia.

Para tanto, foram analisadas imagens de capa e da editoria policial dos jornais publicados entre 01 de dezembro de 2010 e 23 de fevereiro de 2011. A fim de categorizar as fotos encontradas, foi criada 
uma tabela, com base nas definições de violência de Wainberg (2005) e Michaud (1984 apud DIAS, 2003), com graus que variam de 0 - em que não há expressões de violência, a 5 - maior grau, com imagens de cadáveres e, em casos excepcionais, corpos mutilados. Os números encontrados foram cruzados entre si, gerando análise quantitativa quanto aos graus mais evidentes de violência, bem como qualitativa quanto ao destaque dado pelo periódico ao tema. Para uma análise mais aprofundada com relação aos conceitos técnicos utilizados, foram escolhidas duas imagens aleatoriamente, com diferentes graus de violência.

\section{Metodologia}

Bardin (2000) utiliza somente três passos para a pesquisa: a pré-análise, que consiste na escolha e organização dos documentos que serão analisados, na formulação das hipóteses e objetivos, e na elaboração dos indicadores que fundamentam a interpretação; a exploração do material, fase da análise propriamente dita, que consiste basicamente em pôr em prática as decisões tomadas e administrá-las; e, por fim, o tratamento dos resultados obtidos e a interpretação.

Com o objetivo de investigar o tratamento dado pelo jornal Tribuna do Paraná às imagens e fotografias sobre violência e morte nas páginas policiais e na capa, foi desenvolvida a pesquisa através de análise principalmente quantitativa. Entretanto, foram feitas incisões qualitativas a fim de exemplificar o resultado obtido na análise.

Dificilmente um pesquisador adjetivado como quantitativo exclui o interesse em compreender as relações complexas. O que tal pesquisador defende é que a maneira de chegar a tal compreensão é por meio de explicações ou compreensões das relações entre variáveis. Segundo, sem dúvida, pode-se conceber as múltiplas atividades que compõem o processo de pesquisa como um ato social de construção de conhecimento. (GÜNTER, 2006, p.202).

Dessa forma, as pesquisas quantitativa e qualitativa se complementam de modo a criar uma variável que esteja em acordo com o meio social estudado pelo pesquisador.

Nesse sentido, ao se criar uma tabela em que se classificam as imagens em graus de violência, pode-se considerar que a pesquisa qualitativa precede a quantitativa, na medida em que é preciso definir critérios de seleção objetivos para se classificar as imagens segundo o grau X ou Y. Quando se há junção dessas formas de pesquisa científica, tem-se o que se pode denominar “Análise de conteúdo”, como cita Moraes (1999, p.8):

A análise de conteúdo constitui uma metodologia de pesquisa usada para descrever e interpretar o conteúdo de toda classe de documentos e textos. Essa análise, conduzindo a descrições sistemáticas, qualitativas ou quantitativas, ajuda a reinterpretar as mensagens e a atingir uma compreensão de seus significados num nível que vai além de uma leitura comum.

Dessa forma, ao classificar esses dados em subcategorias, o pesquisador reinterpreta os dados seguindo os critérios pré-estabelecidos na pesquisa. No caso do jornal Tribuna do Paraná, foram utilizados critérios técnicos de análise de imagem, tais como enquadramento, iluminação, composição fotográfica, além de serem considerados os elementos que compõem a imagem, a fim de criar um cenário onde se possa vislumbrar o uso da fotografia não só como meio informativo, mas também como instrumento criador de sensações no leitor do periódico.

\section{Fotojornalismo}

Por ser uma atividade relativamente recente, datada do século XIX, quando alguns entusiastas apontam a câmera para fatos cotidianos a fim de publicar essas imagens com intenção testemunhal, a fotojornalismo não possui uma definição clara quanto à sua significação. Uma das significações mais aceitas atualmente é dada por Souza (2004, p.11-12):

[...] entendemos por fotojornalismo a actividade que pode visar informar, contextualizar, oferecer conhecimento, formar, esclarecer ou marcar pontos de vista (“opinar”) através da fotografia de acontecimentos e da cobertura de assuntos de interesse jornalístico. Este interesse pode variar de um para outro órgão de comunicação social e não tem necessariamente a ver com os critérios de noticiabilidade dominantes.

Ou seja, a determinação de fotojornalismo não está diretamente ligada aos critérios de noticiabilidade 
que permeiam o fazer jornalístico, mas segue critérios próprios relacionados aos conceitos de fotografia, juntamente com a ambição de informar. Dessa maneira, o fotojornalismo pode ser considerado como o ato de informar através da fotografia, no qual o texto pode aparecer como contextualizador da mensagem transmitida através da imagem.

O surgimento da atividade fotojornalística está diretamente ligado à necessidade de representação imagética da realidade, sem, no entanto, deixar de lado a beleza da imagem. "Desde os primórdios da fotografia as guerras foram campo fecundo para o exercício fotográfico. [...] Como consequência, a estética do trabalho fotojornalístico de alguns fotógrafos passou a aproximar sua obra com a arte.” (COUTINHO 2010, p.11). Seguindo esses parâmetros, o fotojornalismo, mais que informar, passa a se utilizar de meios estéticos para atrair o leitor. Como exemplos, podem ser tomadas imagens de Cartier-Bresson e Robert Capa, que, embora trazendo conteúdo informativo, privam pela estética como aspecto de fundamentação para prender a atenção do espectador.

Em meados do século XIX, com o crescente interesse pela ideia de veracidade absoluta, transmitido pelo fotojornalismo, começa a surgir o discurso da objetividade fotojornalística, que visava driblar a censura e a manipulação das informações, além de promover maior credibilidade ao trabalho do fotógrafo. Após o final da Primeira Guerra Mundial, com a acentuação da busca por imagens mais nítidas e desvencilhadas da manipulação através da ajuda do objeto (ou pessoa) fotografado, os manuais sobre fotojornalismo começam uma tentativa de desprendimento do ofício de fotojornalista com o campo das belas artes e da estética.

A fotografia como linguagem surgiu no final do século XIX como produto da Revolução Tecnológica e se desenvolve pela necessidade de registrar os fatos sociais de maneira mais rápida e fiel.

Durante a maior parte de sua história, a imagem fotográfica foi observada através de uma postura conceitual carregada de uma forte preocupação com a objetividade e o realismo. Isto fez com que a subjetividade e a ficcionalidade da fotografia ficassem em segundo plano. Atualmente com o desenvolvimento das tecnologias de imagem digital estas posições buscam uma nova relação de equilíbrio. (BURMESTER, 2006, p.1).
A imagem fotográfica, que já foi tida como realismo indubitável pelos teóricos, bem como pelo senso comum, por se tratar do congelamento de uma parte da realidade, hoje não tem mais essa característica. Mauad (1996, p.2) diz que "O caráter de prova irrefutável do que realmente aconteceu, atribuído à imagem fotográfica pelo pensamento da época, transformou-a num duplo da realidade, num espelho, cuja magia estava em perenizar a imagem que refletia." Porém, essa ideia já foi refutada por várias correntes teóricas, que hoje tratam a imagem como simples representação parcial daquilo que aconteceu, retratada sob o ponto de vista do fotógrafo e subordinada à subjetividade do mesmo. Sendo assim, pode-se dizer que o ato fotográfico depende, além da exposição à luz, do enquadramento dado pelo fotojornalista, que dará mais ênfase a esse ou àquele aspecto do fato social retratado, criando uma postura em relação ao mesmo, o que põe em xeque a objetividade intransponível da fotografia.

Com o desenvolvimento de novas técnicas para captação e edição de imagens, alguns aspectos da rotina do profissional de fotojornalismo passaram a ser reconfiguradas. (PEIXOTO; JUNIOR, 2006, p.2):

Pode-se citar desde uma preocupação diferenciada com o enquadramento ou a seleção de ângulos mais trabalhados, até a escolha de pautas as quais pudessem cada vez mais se conectar com um conceito que acabara por se desenvolver dentro das redações: o do all news.

Dessa forma, a busca pela informação imagética começa a criar parâmetros próprios, dando início ao que se pode chamar de critérios de noticiabilidade, os quais são característicos ao fazer fotojornalístico. Estes, apesar de não serem os mesmos, mantêm certas relações com os critérios de noticiabilidade jornalísticos convencionais, estudados nas academias como princípios básicos do jornalismo tradicional. Como um desses princípios, Munhoz (2006) cita a velocidade. Segundo o autor, os leitores buscam na fotografia o registro do momento exato do fato retratado. Essa atitude do fotógrafo, em congelar o momento exato, transfere maior veracidade à informação e fidelidade ao momento retratado, dando a sensação ao leitor de estar presente e ter pleno conhecimento acerca do que está sendo noticiado. 
[...] a estrutura da fotografia não é uma estrutura isolada; ela comunica pelo menos com uma outra, que é o texto (título, legenda ou artigo) de que qualquer fotografia de imprensa vem acompanhada. A totalidade da informação é portanto suportada por duas estruturas diferentes (das quais uma é linguística); estas duas estruturas são concorrentes, mas como as suas unidades são heterogêneas, não podem misturar-se; aqui (no texto), a substância da mensagem é constituída por palavras; lá (na fotografia), por linhas, superfícies, tons. (BARTHES, 1984, p.2).

No entanto, para que se possa ter uma noção clara e completa sobre a mensagem, é preciso que se faça uma análise sobre cada uma dessas estruturas separadamente. E somente quando se estiver esgotado o estudo sobre cada uma dessas partes que compõem a mensagem jornalística é que se poderá ter uma noção mais clara sobre como elas se complementam, dando significação plena ao informativo. Mas, para que haja uma completa análise em relação aos elementos componentes do texto jornalístico, é preciso, antes, separá-los em subcategorias.

Seguindo essa lógica, Barthes (1990, p.20) afirma que há uma inversão histórica a respeito da função do texto e da imagem. “A imagem já não ilustra a palavra; é a palavra que, estruturalmente, é parasita da imagem; [...] na relação atual, a imagem já não vem esclarecer ou 'realizar' a palavra; é a palavra que vem sublimar, patetizar ou racionalizar a imagem". Ou seja, o que antes era mera ilustração da notícia, hoje é visto como meio informativo. E o texto escrito, segundo Barthes, é utilizado apenas para situar o leitor no espaço físico e temporal onde o fato ocorreu. Essa ideia transforma a fotografia numa espécie de representação da realidade mais forte do que o próprio texto jornalístico, dando maior significação ao texto imagético. Dessa maneira, pode-se afirmar que, apesar de não se conceituar mais a imagem como representação fidedigna da realidade, mas sim como um recorte estrutural da mesma, existe uma funcionalidade informativa na fotografia que não está representada no texto escrito.

Característico dos anos 70, o uso restrito da fotografia foi sendo modificado com a facilidade propiciada pelo desenvolvimento de novas tecnologias. Hoje é comum observar nos periódicos um número considerável de imagens, sobretudo na capa, onde as fotos normalmente ocupam espaço relativamente grande. "A fotografia digital provocou uma ruptura entre os profissionais da imagem, principalmente dos fotojornalistas" (OLIVEIRA; VICENTI, 2009). Com a chegada do digital, a partir do final dos anos 1980, essas mudanças estruturais exigiram ainda mais alterações na forma de fazer, além de permitirem ao fotojornalista trabalhar de maneira mais solta, produzindo mais. Sendo assim, esses avanços tecnológicos e conceituais permitem que seja dado maior espaço às fotografias no jornalismo impresso, uma vez que estas acabam por chamar o leitor para a matéria relacionada.

\section{Violência e sensacionalismo}

A aproximação do meio de comunicação com o leitor é fundamental no processo jornalístico. Todavia, essa aproximação ocorre de acordo com as características do meio, bem como do público-alvo. Em jornais populares é comum a utilização do sentimentalismo para atrair a atenção de leitor. A esses periódicos, é dado o rótulo de sensacionalistas. Amaral (2005, p.2) afirma o seguinte:

Entendemos que o sensacionalismo é historicamente recorrente e manifesta-se em vários graus e de diversas maneiras, por isso não devemos tratar do fenômeno in totum. Rotular um jornal de sensacionalista é enfatizar, de uma maneira geral, que ele se dedica a provocar sensações, prática hoje generalizada.

Pode-se dizer, portanto, que o sensacionalismo está presente, de maneira geral, no processo de produção jornalística, uma vez que a provocação de sensações é uma prática constante no cotidiano jornalístico. Desde as academias aprende-se que o texto da matéria deve condizer com a realidade do leitor, e a isso é dado o nome de humanização. Essa maneira de construir a reportagem provoca sensações no leitor.

Para Pedroso (2001), o sensacionalismo é um modo de produção discursiva da informação de atualidade, processado "por critérios de intensificação e exagero gráfico, temático, lingüístico e semântico, contendo em si valores e elementos desproporcionais, destacados, acrescentados ou subtraídos no contexto de representação e construção do real social” (p.123). Os boxes que circundam as imagens 
e textos relativos à morte, acidentes, assaltos, entre outros crimes, bem como os títulos e legendas expansivos podem ser considerados elementos que supervalorizam assuntos que não mereceriam tais proporções, dando-lhes esse caráter sensacionalista.

Angrimani (1995, p.16) diz: "Sensacionalismo é tornar sensacional um fato jornalístico que, em outras circunstâncias editoriais, não mereceria esse tratamento”. Esse autor defende a ideia de que o caráter de sensacionalismo está contido na mensagem, na forma como ela trata o tema que, em outros periódicos não seria pautado, ou o seria, mas de modo mais brando. Assim, pode-se dizer que quando um jornal trata a morte como espetáculo, ele sensacionaliza o assunto, tanto no sentido da visibilidade dada a um tema relativamente comum, quanto pela proximidade criada com o leitor.

Nos periódicos chamados sensacionalistas, um dos temas mais explorados é, sem dúvida, a violência. Ela é explícita nas imagens de capa e nos textos. Entretanto, esse assunto não está presente apenas em tais periódicos. Angrimani (1995) defende que esses periódicos apenas explicitam aquilo que os ditos "não sensacionalistas" ocultam na forma editorial. A violência é intrínseca ao ser humano, como afirma Odália (2004, p.13): "O viver em sociedade foi sempre um viver violento. Por mais que recuemos no tempo, a violência está sempre presente, ela sempre aparece em várias faces”. Dessa forma, pode-se afirmar que a violência é um processo natural do convívio social.

Segundo Wainberg, (2005, p.34), “A definição de violência mais referida na literatura especializada afirma ser um 'comportamento agressivo com intenção de causar dano (físico ou psicológico) na vítima’”. Ou seja, para Wainberg, a violência pode ser definida como um ato intencional. A imagem pode ser violenta em várias instâncias e graus de intensidade. Ela pode agredir o sujeito retratado ou o espectador. Porém, segundo esse raciocínio, apenas a imagem em si não pode ser violenta, já que o fato aconteceria independentemente da vontade ou não de se agredir quem terá acesso a ele. Somente quando existe essa intenção é que há, de fato, violência. Já para Michaud (apud DIAS, 1984, p.111), a violência pode ser entendida segundo o ato em si, ou a interpretação que se faz dele: "Violência são os fatos tanto quanto nossas maneiras de apreendê-los, de julgá-los, de vê-los - ou de não vê-los”. Sendo assim, ela está não apenas no emissor, mas também no receptor da mensagem; ou seja, a forma como o indivíduo vê a imagem e a interpreta é que irá julgá-la violenta ou não. Isso acontece independentemente da intenção dos indivíduos atuantes.

Em se tratando de imagens, a violência pode ir além daquilo que o senso comum concebe como tal. Com o desenvolvimento dos meios de comunicação, a violência transforma-se num dos principais assuntos pautados pelos meios de comunicação convencionais. Em jornais ditos sensacionalistas, ela se torna uma fonte principalmente de imagens, que atraem o leitor. Dessa forma, para que se possam analisar as imagens que pautam a violência no jornal Tribuna do Paraná, criou-se uma categorização, tendo como base as definições de violência de Wainberg e Michaud, e tomando como partida as imagens encontradas nas páginas desse diário, conforme mostra a Tabela 1.

\begin{tabular}{|c|c|}
\hline $\begin{array}{l}\text { GRAU DE } \\
\text { VIOLÊNCIA }\end{array}$ & O QUE PODE APARECER \\
\hline 1 & Apreensões de drogas, armas, ofensa moral leve, etc. \\
\hline 2 & $\begin{array}{c}\text { Ofensa moral grave / ferimentos leves / danos leves ao patrimônio / flagrante/reconstituição de } \\
\text { crimes }\end{array}$ \\
\hline 3 & Ferimentos graves / danos graves ao patrimônio / danos ambientais / poça de sangue \\
\hline 4 & Insinuação de cadáveres \\
\hline 5 & Cadáveres / pedaços mutilados de corpos \\
\hline
\end{tabular}




\section{Ética no jornalismo}

A ética pode ser entendida como "uma ciência da moral, pois questiona ao buscar por quê e em quais condições determinada ação é considerada boa ou má, até que ponto ajuda a construir a identidade de uma nação, grupo ou pessoa” (RIBEIRO, 2000, p.137). No jornalismo, os valores éticos traçados por um código determinante e universal à profissão visam diminuir os embates sofridos diariamente pelos profissionais da área. No entanto, esses valores são mutáveis, uma vez que devem condizer com o processo histórico-social a que se referem, alterando-se de acordo com o processo histórico sofrido pela sociedade, sempre respeitando seus valores. No jornalismo, em particular, a ética pode ser considerada como um conjunto de princípios condizentes com os padrões morais aceitos socialmente.

O discurso ético no campo das comunicações, em especial no jornalismo, é deveras ultrapassado. Segue-se um manual de boas maneiras, formas de agir e de fazer que pouco condizem com a realidade da profissão, em que o jornalista depara-se com dilemas deontológicos inerentes ao dia a dia. Bucci (2002, p.09) diz que:

Às vezes, o debate em torno do comportamento da imprensa parece se reduzir a um receituário de boas maneiras. Uma confraternização de gala. Basta que não se profiram palavrões, que os profissionais se movimentem como cavalheiros e damas da corte, que não se ofendam os interlocutores e que a privacidade dos convivas seja mantida na mais sagrada inviolabilidade.

Segundo o referido autor, o jornalismo pode ser visto como um "sarau literário de Paris do início do século XIX”, uma vez que se trata de um conjunto de etiquetas que implicam um modo de fazer predeterminado da matéria jornalística, que ostenta o bem estar dos indivíduos envolvidos na mesma. Dessa forma, o Código de Ética acaba transformando-se numa mera listagem de atitudes e termos aceitos socialmente. Estes podem ser perfeitamente utilizados sem que se atinja negativamente a ordem e os bons costumes. Assim, a partir do uso desses cerimoniais estruturados, garante-se a credibilidade na informação. Ou seja, se o cerimonial é aceito como reafirmador da moral, então é aceito como verdade indiscutível.
Entretanto, como a sociedade é constantemente mutável, esses códigos deontológicos devem seguir as transformações sociais, a fim de assegurar o reforço à moral e aos bons costumes, reafirmando a credibilidade do periódico em questão. Assim, através de novos incisos procura-se garantir a eficácia e a aplicabilidade de tais termos éticos.

Ao mesmo tempo em que é ampliado o número de códigos, subscritos por categorias profissionais e empresariais no campo da Comunicação e do Jornalismo, cresce também a análise sobre a eficácia e a utilidade das referências deontológicas na área. (KARAN, 1997, p.3).

Isso porque mesmo sendo um tratado de boas maneiras, o Código de Ética nem sempre é seguido pelos jornais, pondo em xeque certas condutas esperadas quando da publicação de certos fatos noticiosos, principalmente no que diz respeito à violência, morte ou casos em que a integridade física e/ou moral do indivíduo possa ser afetada.

No fotojornalismo, a questão ética é ainda mais delicada, visto que a imagem está submetida à subjetividade do fotógrafo, que para a composição de cenários utiliza diversos objetos, a fim de criar mensagens e significações de acordo com aquilo que se pretende oferecer ao leitor como ilustração ou parte da informação-notícia. Segundo Canabarro (2005, p.26), a imagem, enquanto produto cultural, "é uma construção feita por um sujeito mediador, o fotógrafo, que seleciona pessoas e elementos e os enquadra na bidimensionalidade de um espaço a ser recortado.” Esse enquadramento promovido pelo fotógrafo enquanto difusor de informações jornalísticas, teoricamente é submetido aos preceitos éticos e deontológicos que permeiam a profissão. Contudo, em alguns casos, esses preceitos são deixados de lado, em função da vendagem do periódico, que se estabelece pelas imagens de seres humanos em situações esdrúxulas e desumanas.

Uma das formas mais comuns de desobediência ao Código Ético diz respeito à manipulação das fotografias, que pode comprometer a veracidade da informação e, consequentemente, a credibilidade do meio informativo.

Os acontecimentos recentes, envolvendo imagens manipuladas, revelam o sério problema que a 
falta de ética e de escrúpulos pode acarretar na veracidade das informações jornalísticas, descaracterizando o contexto real da imagem, tornando-a mais atraente e sedutora ao público. (OLIVEIRA, 2010 p.429).

Apesar dessa credibilidade duvidosa, criada a partir da manipulação imagética, a sedução sofrida por parte do leitor quando um periódico extrapola em certos aspectos, tais como luz, enquadramento e objetos pertencentes ao contexto, é imediata.

Essa manipulação, alteradora do contexto e sentido do fato retratado, é exemplo clássico, cometido no fotojornalismo brasileiro, de falta ética.

\section{O Tribuna do Paraná em números}

Segundo os critérios já apresentados, foram analisadas 567 fotografias do jornal diário Tribuna do Paraná.

Os dados apontam para os seguintes números: $68 \%$ das fotografias apresentam algum grau de violência, sendo a minoria, ou seja, aproximadamente $15 \%$, na primeira página do jornal. A grande maioria (85\% das imagens com grau de violência) está inserida nas páginas interiores, na editoria denominada "Segurança Pública"; 53\% das imagens apresentam grau 1 de violência. A maioria é a fotografia de indivíduos suspeitos de algum crime, aparecendo em primeiro plano seu rosto com o distintivo da polícia ao fundo, o que pode denegrir a imagem dessas pessoas, já que elas não são oficialmente culpadas dos atos noticiados. Também houve algumas imagens de armas e drogas apreendidas, porém em menor valor quantitativo. O grau 2 é apresentado por 9\% das imagens, sendo os motivos variados, entre danos leves ao patrimônio, como acidentes automobilísticos, ferimentos leves nos indivíduos e uma imagem de flagrante de um crime, captada por câmera de segurança, além de uma foto de reconstituição. Houve também $16 \%$ das fotografias com grau 3 , formadas, em sua maioria, por imagens de ferimentos graves, danos ambientais e patrimoniais de alto nível, como queimadas e acidentes em que houve perda total dos bens, além de duas imagens com poças de sangue em primeiro plano. A categoria 4 apresentou 10\% das imagens com algum grau de violência, sendo que dessas, $78 \%$ estavam nas páginas interiores do jornal. O grau mais extremo da categorização, chamado grau 5 , em que cadáveres e pedaços de corpos mutilados são os objetos, representou 12\% das imagens. Porém, houve apenas duas imagens dessas na capa do periódico. Apenas 32\% de todas as imagens coletadas, entre capa e páginas policiais, apresentam grau 0 , ou seja, não possuem valor violento. O gráfico 1 mostra esses dados. 
Gráfico 1 - Número de ocorrências dos graus de violência nas imagens

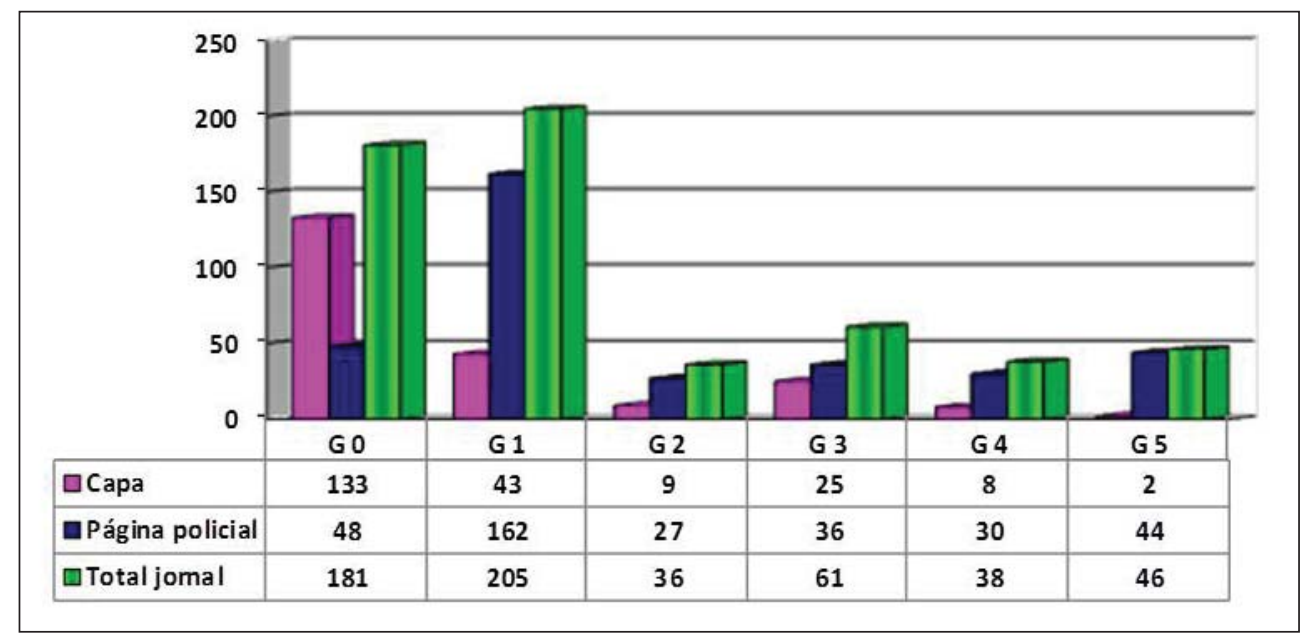

Das 347 imagens encontradas no interior do jornal durante o período coletado, as de grau 5 somam 44, ou seja, $13 \%$ das fotografias, sendo as encontradas em terceiro lugar, atrás das de grau 1 (maior representatividade, com $46 \%$ do total) e das de grau 0 , ou seja, sem cenas violentas presentes, que atingem um total de $14 \%$ das figuras. As de grau 3 são $10 \%$, as de grau 4 formam $9 \%$ e as de grau 2 vêm em último lugar, com 8\% do total. Quando se trata da capa do jornal, o número de imagens é inversamente proporcional ao grau de violência apresentado, ou seja, à medida que aumenta o grau categorizado, diminui o montante de imagens apresentado no periódico. A exceção é o grau 3, que apresenta 11\% das imagens, estando em terceiro lugar nas figuras mais presentes durante o período. As de grau 0 somam $60 \%$ das fotografias da primeira página e geralmente tratam de assuntos esportivos ou sexo, formando o tripé de vendagem do jornal. As de grau 1 vêm em segundo lugar, com 20\%, seguidas pelas de grau 3, já citadas. Depois vêm as imagens de grau 2 e grau 4, ambas com $4 \%$ das aparições na primeira página da Tribuna do Paraná. Em último lugar está a categoria 5 , que soma $1 \%$ de todas as imagens da capa do jornal.

No gráfico 2, pode ser observada a relação percentual de imagens com algum determinado grau de violência, comparativamente ao total de imagens coletadas na capa do periódico:

Gráfico 2 - Porcentagem de imagens de violência nas primeiras páginas do jornal

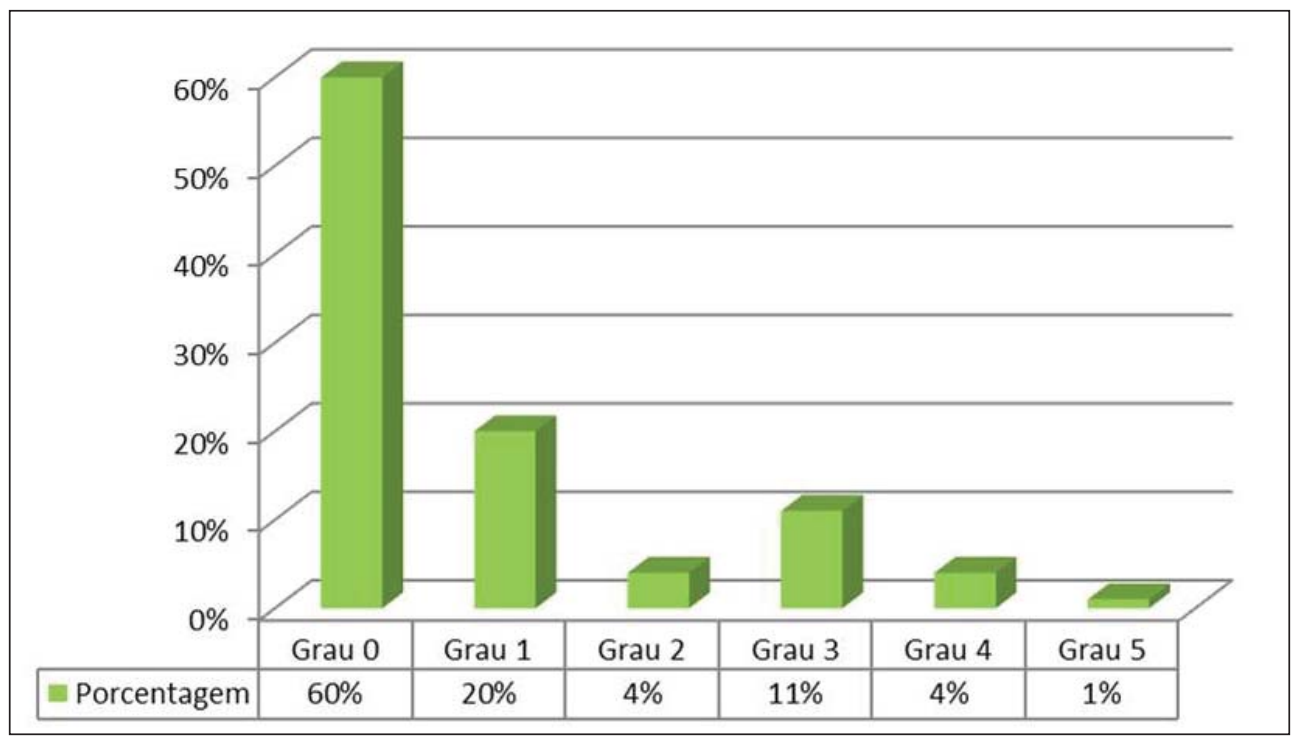


Pode-se observar, através dos dados do gráfico 2 , que embora $40 \%$ das imagens coletadas na capa da Tribuna do Paraná correspondam a algum grau de violência, apenas 1\%, ou seja, duas das imagens publicadas na capa no período coletado são de cadáveres, representativos do grau 5 , o que denota certo cuidado por parte do periódico em evitar tais fotografias expostas nas capas dos exemplares.

No gráfico 3, pode-se observar porcentagem de imagens com algum grau de violência nas páginas policiais, em relação ao total de imagens coletadas na editoria de polícia:

Gráfico 3 - Porcentagem de imagens de violência nas páginas policiais do jornal

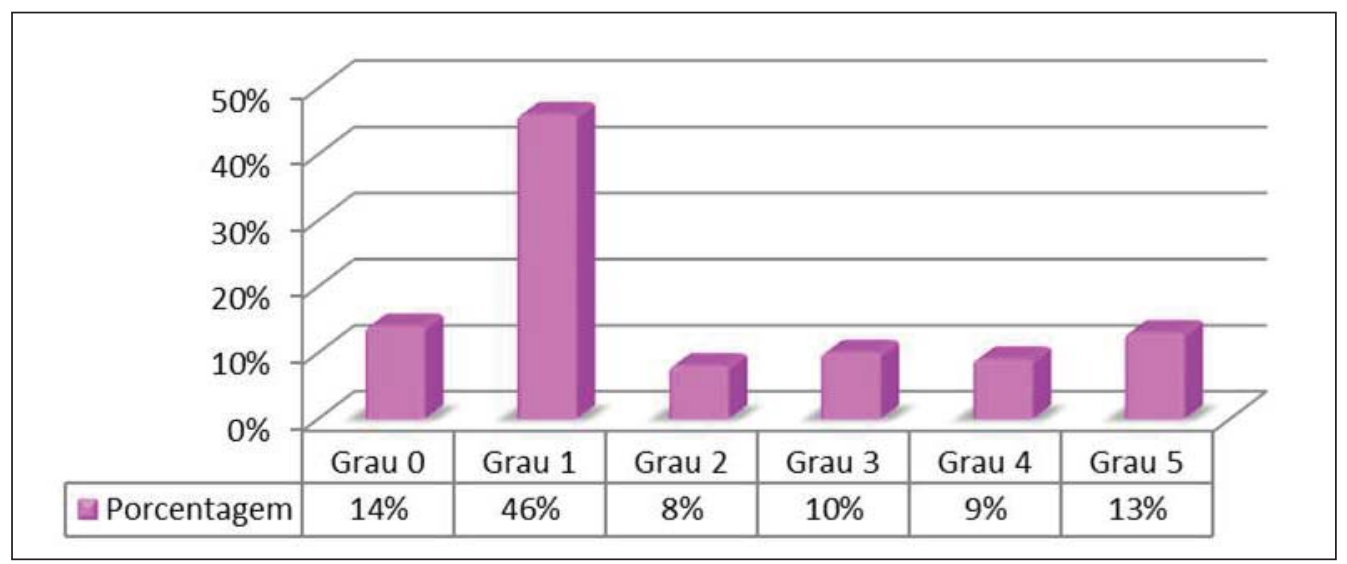

O gráfico 3 denota o apelo sofrido pelas páginas policiais no que diz respeito às imagens com algum grau de violência, sobretudo imagens de grau 1 , que corresponde às fotografias que possam inferir ofensa à moral do personagem retratado, como ocorre em casos nos quais a foto do indivíduo é publicada, acusando-o de crimes dos quais não houve sequer julgamento. O jornal acaba cometendo, inclusive, deslizes éticos no que se refere ao respeito à intimidade, privacidade e honra do cidadão, conforme explicita o artigo $6^{\circ}$ do Código de Ética dos jornalistas.

Comparativamente, o jornal opta em expor maior número de imagens sem graus de violência na capa do que em suas páginas internas. Porém, as imagens de grau 3 são as mais exploradas entre as violentas da primeira página, representando $11 \%$ das fotografias desse local, enquanto na editoria de Segurança Pública formam $10 \%$ do total, diferença quase insignificante no que diz respeito à quantidade de imagens. Entretanto, quando se constata que em $40 \%$ das imagens da capa do periódico está presente alguma agressividade, em qualquer circunstância que seja, pode-se afirmar que o apelo imagético é bastante forte no que diz respeito ao sensacionalismo.

A utilização de uma foto de cadáver na primeira página torna-se desnecessária no que diz respeito à difusão da notícia. Informações como essa podem ser retratadas de maneira mais branda, sem o apelo visual que a foto oferece. Os personagens compositores da imagem oferecem caráter mais pessoal à mensagem, fazendo com que o leitor se aproxime da situação, dando à matéria o caráter sensacionalista citado por Angrimani (1995).

Todavia, a partir desses dados pode-se observar que o jornal opta pela concentração de imagens apelativas na editoria a que se refere o assunto, ou seja, nas páginas dedicadas aos assuntos policiais e de segurança pública, havendo menor quantidade desses elementos na capa, lugar de primeiro contato do leitor. Porém, a parcela que está voltada ao grau mais alto, em geral, está envolta por boxes que lhe dão maior visibilidade, mesmo em páginas interiores. Na capa são usados grafismos em imagens de graus mais amenos, como os graus 2, 3 e 4 . Essa forma de fazer é característica dos jornais populares, como afirma Amaral (2005, p.3): "Outro equívoco muito comum ao tratarmos do sensacionalismo é simplesmente taxar o conteúdo dos veículos auto-intitulados populares de degradação cultural”. Mesmo usando de artifícios sensacionalistas para atrair o leitor, tais periódicos procuram adequar seu conteúdo a uma linguagem jornalística que agrada determinado público. Ou seja, sua mensagem está contida nos parâmetros culturais desses indivíduos; embora 
não se ajuste àquilo que é defendido pelo jornalismo convencional, o caráter jornalístico dessa mensagem é inegável. No entanto, o fato de que alguns termos éticos que regem a profissão de jornalista são ignorados não pode ser deixado de lado, uma vez que tal atitude atinge diretamente as fontes e a qualidade da informação recebida pelo leitor.

\section{Análise de conteúdo}

A imagem pode ser considerada uma mensagem jornalística. Como tal, ela é formada por partes constituintes. Entre essas partes pode-se listar, segundo Barthes (1984), o texto, a legenda, o título, além dos objetos que compõem o cenário fotográfico e a pose dos personagens, que dão determinada significação à mensagem.

A totalidade da informação é, portanto, suportada por duas estruturas diferentes (das quais, uma é linguística); estas duas estruturas são concorrentes, mas como as suas unidades são heterogêneas, não podem misturar-se; aqui (no texto), a substância da mensagem é constituída por palavras; lá (na fotografia), por linhas, superfícies, tons. (p.2).

Cada um desses elementos que compõem a mensagem fotográfica dá suporte à totalidade da mesma. Dessa forma, cada um pode ser analisado separadamente, ou num conjunto, de maneira a dar sentido ao contexto da matéria jornalística. No caso da fotografia de violência, os elementos que dão tal significação ao contexto são mais acentuados, como títulos com palavras hostis, cadáveres ou pessoas em situações grotescas, ou legendas agressivas. Esses elementos dependem da subjetividade do fotografo e da linha editorial seguida pelo periódico.

Sendo assim, os elementos componentes da fotografia estruturam um quadro que vai além da informação, buscando atrair os olhares do leitor a determinados pontos da figura. Isso se dá através da composição gráfica, que pode atribuir maior ou menor juízo de determinado valor, como, no caso, a violência. Esse grau é determinante na caracterização do jornal que publica a foto como sensacionalista ou não. Sobre isso, Sousa (2004, p.65) afirma que:

Barthesianamente, poderíamos considerar que entre os mais relevantes elementos potencialmente conferidores de sentido a uma mensagem fotojornalística se inscrevem o texto, insuflador de sentido à imagem, e os elementos que fazem parte da própria imagem, como a pose, a presença de determinados objetos, o embelezamento da imagem ou dos seus elementos, a truncagem, a utilização de várias imagens, etc.

Ao apresentar um cadáver de forma evidenciada na imagem, o jornal confere-lhe certa mensagem que potencializa o fato retratado de forma a assumir determinado aspecto em relação ao acontecimento que pautou tal mensagem jornalística.

A figura 1 , representativa do grau 5 , presente em $13 \%$ das imagens do interior da Tribuna do Paraná, circulada no jornal do dia 15 de dezembro de 2010, mostra uma criança olhando os restos mortais de um indivíduo que foi encontrado morto. O título dado à notícia ilustrada por essa imagem é "Cadáver é encontrado por pescador em Colombo”. O texto da notícia contém informações a respeito do estado em que o corpo estava - "Ele está de cuecas e com as calças nos pés.” - além de detalhes sobre como o corpo foi encontrado, dizendo que o pescador "fisgou o pé do cadáver”. Essa linguagem popularesca faz com que o jornal Tribuna do Paraná se aproxime do extinto Notícias Populares, durante seu período mais ácido. A linguagem esdrúxula utilizada para repassar a foto ao leitor não corrompe a veracidade dos acontecimentos, contudo os ridiculariza, insuflando sentido grotesco e dando aspectos sensacionalistas a um fato cotidiano, mas que, tratado sob a ótica dos parâmetros éticos que regem o fazer jornalístico, deveria ser abordado mais cuidadosamente, visto tratar-se de assunto tão delicado.
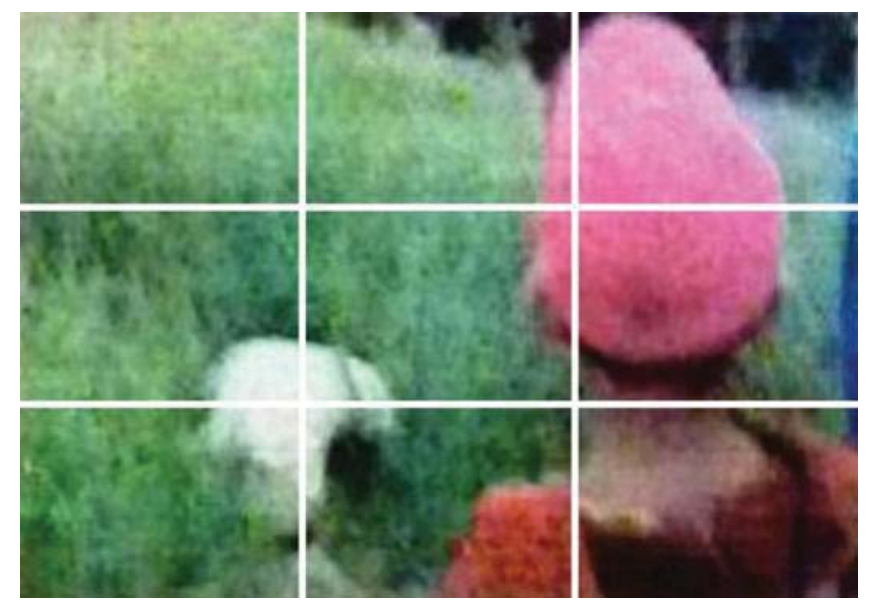
Como se pode observar na figura, o corpo encontrado está enquadrado em um dos chamados pontos de ouro - pontos de intersecção das linhas guia que divide a imagem de acordo com a regra dos terços, representante da supervalorização do mesmo. Embora esteja de costas, pode-se notar que quem está olhando a cena é uma criança. Ela está posicionada de forma a ocupar todo o terço direito da imagem. Sua roupa e boné vermelhos contrastam com o verde do mato e com a figura do cadáver, criando uma harmonia no que diz respeito à coloração da imagem.

O capítulo III do Código de Ética dos jornalistas fala da responsabilidade profissional: "O jornalista não pode divulgar informações de caráter mórbido, sensacionalista ou contrário aos valores humanos, especialmente em cobertura de acidentes”. Nesse caso, a Tribuna do Paraná vai totalmente de encontro a esse parágrafo, desrespeitando os princípios morais mais básicos que regem a profissão.

Mesmo que o foco principal seja o homem encontrado morto, a imagem de uma criança observando o corpo cria uma dramaticidade na cena, provocando sensações no leitor. Essa promoção de sentidos é característica de jornais ditos sensacionalistas, conforme afirma Camargo (2003, p.10):

Tratamos como sensacionalista a presença de informações que não se justificavam jornalisticamente, bem como a presença de uma construção narrativa que parecia objetivar a aproximação entre leitor, fato e personagens da notícia, além de causar sensações como a solidariedade e a idéia de cotidianidade ao leitor.

A criança configura um personagem desnecessário na construção fotojornalística. Ela nada acrescenta em informação. Porém, a figura infantil desperta a solidariedade do leitor, provocando nele o sentimento de proximidade com a situação retratada, o que pode ser uma estratégia de venda.

Por outro lado, dentre as imagens de cunho violento, o grau mais presente é o chamado grau 1 . Pode-se observar que, em sua maioria, essa categoria apresenta imagens de pessoas que são suspeitas de cometer crimes, mesmo que não tenham sido condenadas ou sequer julgadas legalmente. Grande parte são fotografias de plano fechado, como o exemplo da figura 2.

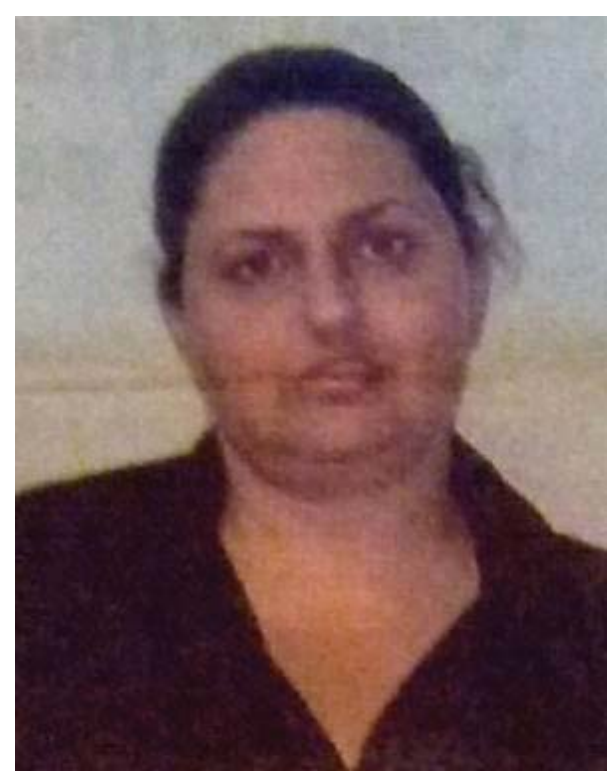

Com o título "Dá golpe do consórcio com ajuda da mãe”, essa notícia ainda acusa a mulher de tentar fugir. Já no corpo do texto, a moça é apontada como suspeita de crimes e não como acusada ou culpada, como podem sugerir as chamadas. O parágrafo VIII do Art. $6^{\circ}$ do Código de Ética diz que "é dever do jornalista respeitar o direito à intimidade, à privacidade, à honra e à imagem do cidadão”. Quando há divulgação de imagens do tipo 3x4 nas páginas policiais, seguidas de títulos desse cunho, o jornal decreta a culpa, por qualquer crime, de quem está sendo retratado. Com isso, pode-se desconsiderar o papel do jornal quanto à preservação dos princípios éticos e deontológicos que regem a profissão.

A imagem não possui grandes recursos de enquadramento ou iluminação. Ela é simples, com características comuns a qualquer fotografia do formato $3 x 4$, no que se refere ao seu aspecto técnico. Souza (2004, p.68) diz: "Entra-se no domínio da composição quando se fala da disposição dos elementos da fotografia tendo em vista a obtenção de um efeito unificado, que, em princípio, é a transmissão de uma idéia ou sensação.” Dessa forma, o caráter simplista da imagem transmite a atenção para o objeto/indivíduo registrado. Ou seja, não são exploradas composições diferentes porque não há necessidade no que diz respeito à intenção do jornal em destacar a fisionomia do indivíduo. Essa atitude do periódico cria um estereótipo em torno do indivíduo, marcando-o perante a sociedade como criminoso, mesmo que não o seja. 


\section{Considerações finais}

Embora as imagens classificadas como de grau 5 representem apenas $12 \%$ das fotografias sobre o tema, ao contabilizar todas as fotos com algum grau de violência, estas formam $68 \%$ das imagens, o que marca o viés sensacionalista do jornal Tribuna do Paraná.

Essas imagens de caráter sensacionalista são assim classificadas pelos recursos de fotografia utilizados na sua produção, o que culmina, muitas vezes, com entraves éticos que podem ser observados nas páginas do jornal em questão. Ainda que esses desvios deontológicos promovam o descrédito da informação em sua totalidade, pode-se perceber que não influenciam drasticamente na vendagem do periódico, uma vez que o mesmo é o segundo de maior tiragem no estado, comprovando a hipótese de que o leitor é atraído por imagens de cunho sensacional ou violento.

Apesar de não serem maioria na capa, as imagens sobre morte, acidentes e outras desgraças humanas aparecem destacadas por outros elementos insufladores de sentido e se apresentam na primeira página como forma de chamar atenção para a editoria de Segurança Pública. Nessas páginas as fotos aparecem com maior frequência e em graus maiores, denotando a despreocupação com a preservação dos indivíduos retratados, já que, quanto mais fortes forem as imagens, maior destaque eles recebem, seja por meio de fotos maiores, seja através de recursos como boxes ou títulos garrafais e em linguagem esdrúxula, como já foi apresentado.

O título e os recursos gráficos servem como complemento à foto na tentativa de extrair sensações dos leitores, trazendo-os para o texto e tentando prendê-los na leitura com detalhes minuciosos acerca dos fatos retratados. Essa característica do jornal Tribuna do Paraná fortalece seu cunho sensacionalista, sempre supervalorizando assuntos referentes à morte, às desgraças humanas e sociais. A preferência editorial em ressaltar tais fatos demonstra que, antes de qualquer coisa, a intenção do veículo é fisgar o leitor e, com isso, aumentar a venda de jornais.

Na visão dos teóricos do jornalismo e do fotojornalismo, essa forma de fazer notícia acaba comprometendo a credibilidade do jornal, impedindo o desenvolvimento do jornalismo, de um fotojornalis- mo sério e de qualidade. Isso porque a preocupação primeira está em ressaltar o grotesco, atípico e demonstrar como o mundo - em especial o Paraná está se tornando um lugar cada vez mais perigoso de se viver. Apesar de o caráter sensacionalista nem sempre representar uma desvalorização cultural, no sentido das imagens ou abordagens textuais utilizadas, o desrespeito aos valores éticos compromete não só o periódico em questão, mas os leitores que se submetem a absorver tais informações sob esse viés. Além disso, compromete também as fontes, que são tratadas como meros personagens de um espetáculo da vida que é vendido a preço de banana.

\section{Referências}

AMARAL, Marcia F. Sensacionalismo, um conceito errante. Intexto, Porto Alegre: UFRGS, v.2, n.13, p.1-13, julho/ dezembro 2005.

ANGRIMANI, Danilo. Espreme que sai sangue: um estudo do sensacionalismo na imprensa. São Paulo: Summus, 1995.

BARTHES, Roland. O óbvio e o obtuso: ensaios críticos III. Rio de Janeiro: Nova Fronteira, 1990.

A mensagem fotográfica. In: O óbvio e o

obtuso. Rio de Janeiro: Nova Fronteira, 1990.

BUCCI, Eugênio. Sobre ética e imprensa. São Paulo, Companhia das Letras, 2002.

CAMARGO, Aline C. Contextualização, objetividade e sensacionalismo na cobertura jornalística de direitos de crianças e adolescentes. In: INTERCOM, CONGRESSO DE CIÊNCIAS DA COMUNICAÇÃO NA REGIÃO SUDESTE, 16, São Paulo - SP, 2011. Disponível em: < http://www.intercom.org.br/papers/regionais/sudeste2011/ resumos/R24-0143-1.pdf>. Acesso em: 18 outubro 2012.

CANABARO, Ivo. Fotografia, história e cultura fotográfica: aproximações. Estudos Ibero-Americanos. Porto Alegre: PUCRS, v.31, n.2, p.23-39, dez. 2005.

FENAJ. Código de Ética dos Jornalistas Brasileiros. Vitória, 2007. Disponível em: <http://www.fenaj.org.br/ materia.php?id=1811>. Acesso em: 18 outubro 2012.

DEBORD, Guy. A sociedade do espetáculo: comentários sobre a sociedade do espetáculo. Rio de Janeiro: Contraponto, 1997.

DIAS, Ana R. F. O discurso da violência: as marcas da oralidade no jornalismo popular. São Paulo: Cortez, 2003.

DUBOIS, Philippe. O ato fotográfico e outros ensaios. Campinas, SP: Papirus, 1994. 
GÜNTHER, Hartmut. Pesquisa qualitativa versus pesquisa quantitativa: esta é a questão? Psicologia: teoria e pesquisa, v.22 n.2, p.201-210, maio-ago. 2006.

KARAM, Francisco J. C. A ética jornalística e o interesse público. São Paulo: Summus, 2004. 1997.

Formação e ética jornalística. São Paulo: Summus,

LIMA, Ivan. Fotojornalismo brasileiro: realidade e linguagem. Rio de Janeiro: Fotografia Brasileira, 1989.

MAUAD, Ana Maria. Através da imagem: fotografia e história interfaces. Tempo, Rio de Janeiro, v.1 n.2, p.73-98, 1996.

MUNHOZ, Paulo César Vialle. Fotojornalismo, internet e participação: os usos da fotografia em weblogs e veículos de pauta aberta. Dissertação (Mestrado em Comunicação e Cultura Contemporâneas). Universidade Federal da Bahia. Salvador, 2006.

ODÁLIA, Nilo. O que é violência. 6.ed. São Paulo: Brasiliense, 2004.

OLIVEIRA, Erivan M.; VICENTINI, Ari. Fotojornalismo: uma viagem entre o analógico e o digital. São Paulo: Cencage Learning, 2009.

O resgate da ética no fotojornalismo: a banalização das imagens nos meios de comunicação. RecifePE, Trabalho apresentado FNPJ - Fórum Nacional de professores de Jornalismo, Abril de 2010.

PEDROSO, Rosa Nívea. A construção do discurso de sedução em um jornal sensacionalista. São Paulo: Annablume, 2001.

RIBEIRO, Jorge Cláudio. A ética como fator de resistência no jornalismo. Revista Brasileira de Ciências da Comunicação, v. 23, n.2, p.137-141, jul/dez 2000.

SODRÉ, M; PAIVA, R. O império do grotesco. Rio de Janeiro: Mauad, 2002.

SOUZA, Jorge P. Fotojornalismo: introdução à história, às técnicas e à linguagem da fotografia na imprensa. Florianópolis: Letras Contemporâneas, 2004.

Uma história crítica do fotojornalismo ocidental. Chapecó: Letras Contemporâneas, 2004.

Recebido em: 22 de abril de 2012 Aceito em: 12 de setembro de 2012 